Built Environment - Special issue

\title{
Introduction
}

Martine Drozdz, Manuel Appert and Andrew Harris

\section{High-rise urbanism in contemporary Europe}

Europe has witnessed during the twenty-first-century its greatest ever period of high-rise construction. From London to Rotterdam, Barcelona, Moscow, Madrid, Vienna, Milan, Turin, Paris, Lyon and Warsaw, European city skylines have become higher, thicker and more diverse. After a fallow period during which very few towers were built (1980-2000), European cities are currently experiencing a renewed interest in this architectural form, following in the footsteps of the United States and emerging economies. While the resurgence of skyscrapers in Europe has, to date, been somewhat modest in terms of height compared to the Middle East or Southeast Asia, it has reached unprecedented proportions in a significant number of European countries, exceeding the post-war boom period, prompting the need to assess the nature of this upward urban growth (current figure 1).

$<$ current Figure 1 about here $>$

This issue of Built Environment explores the processes of contemporary European urban verticalization and examines what these recent upward trajectories indicate about the social, political, economic and cultural dynamics of European urbanisation. Through a combination of particular casestudies across Europe with wider analyses of national and international trends, the issue investigates the relationship in European cities between high-rise built fabric and planning regimes, financial flows, cultural representations, technical innovations, and forms of modernist heritage. Developing cross-disciplinary perspectives and engagement with both academic and practitioner insights, the issue provides an initial sustained assessment of high-rise Europe in the context of a wider world of vertical urbanisms (Graham and Hewitt, 2013; Harris, 2015). 
European cities occupy a special place in the modern history of vertical urbanism. While European industrial architectural and engineering research inspired the construction of the first skyscrapers in the United States (Cohen, 1995), North American vertical architecture became in turn a key reference for post-War European planners in modernising urban centers (destroyed by conflict and plagued by housing shortages) according to a modernist perspective largely inspired by the circulation of references from across the Atlantic (Gartman, 2000). However, contrary to its North American model, European post-War vertical urbanism was crucially characterized by a culture of large-scale urban planning which was mainly the product of highly centralised forms of state intervention, a configuration that helped create distinctive types of European high-rise housing (photograph grand ensemble Clermont or Warsaw). This included the role for new architectural and structural standards, technological innovations and a shared culture of urban engineering in defining a vertical urbanism that spread well beyond European national borders (Taillandier et al., 2009). For example, many French architects and engineers of the post-War 'Reconstruction' period started their career in colonial cities before coming back to the French urban metropole where they applied their expertise (Picard, 1994 ; Fredenucci, 2003; Kasmi, 2017). This expertise was then further circulated to be applied in post-colonial centres, creating a transnational space for European modernist urban references and vertical arts de faire (Verdeil, 2012; Beeckmans, 2014; Stanek, 2012).

$<$ Photograph grand ensemble Clermont or Warsaw $>$

The epitome of the architectural modernisation of European cities in the post-War period, high-rise urbanism was initially characterised by the construction of large-scale residential developments made of slab and point blocks and sometimes large-scale concrete platforms which, following Le Corbusier principles of modernist urban planning, separated high-rises from traffic infrastructures and historical centres (Escher, 1981; Monclus and Dies Medina, 2016). High-rise urbanism was then an essential feature of the expansion of Fordist developmentalist states in Western and Eastern European countries (Swenarton et al., 2014; Hatherley, 2016). As Jane Jacobs et al. (2012: 132) argue, it was 'the materialisation of a specific modernising vision for cities and city life, one that joined the progressive ethos of state-led welfarism with a modernist architectural aesthetics'. During this high-rise peak, 
architectural and urbanism references followed similar developments across Europe with a large number of slab-blocks built on the outskirts of towns and cities, reflecting the importance of decision processes centralised by the post-War central state. But, as Turkington et al. note in their 2004 study, European cities then diverged with regards to the construction and dissemination of a high-rise urbanism. While in Western Europe, most of the high-rise construction stopped in the 1980s, the building of high-rise residential estates continued in Eastern European cities into the 1990s (Turkington et al., 2004: 266) (current Figure 2).

$<$ current Figure 2 about here $>$

During the 1970s and 1980s, European high-rise urbanism became the locus for long-standing processes of demonization and stigmatisation following a series of isolated incidents such as the collapse of Ronan Point Tower in London (1968), the demise of large-scale social housing projects in France (Kaddour, 2016), the broader restructuring and privatisation of public housing in most European countries (Power, 1993; Sailer-Fliege, 1999) and the controversies that followed the construction of stand-alone high-rise office towers such as Tour Montparnasse in Paris or Centre Point in London. After having been one of the fields of experimentation for vertical urbanism, several European cities experienced a reaction against high-rises that correlated with the institutionalization of forms of heritage protection. After modernism, came the valuing of more pastiche or postmodern forms of urbanism, putting the accent more on morphological continuity and the conservation of historical urban centers (Appleyard, 1979; Delafons, 1998; Glauser, 2016). Many heritage lobbies, which became major players in the contemporary regulation of urban planning in European cities, were created in reaction to reconstruction and modernization projects (Backouche, 2016). The contemporary wave of verticalization must be understood in reference to these multiple legacies of a disputed vertical urban past, and is a distinctive feature of the European high-rise context (photograph Vienna or Frankfort).

$<$ Photograph Vienna or Frankfort $>$ 
Nevertheless, the protected skylines of European cities have been troubled in the last fifteen years by new waves of tall buildings and high-rise residential structures, a tendency which has not been limited to the main global urban centres and is affecting a diverse range of cities (Drozdz and Appert, 2012). The number of towers currently under construction exceeds the post-war boom period and high-rises are once again finding a certain legitimacy in European cities (Appert, 2016). This contemporary high-rise urbanism in Europe comes in different sizes and forms. While the resurgence of skyscrapers has been a major phenomenon, including those that had put in place the most drastic anti-tower legislation after the modernist period, the process of verticalization in Europe has been far from linear, has not necessarily happened in the same type of locations, and has not produced an urban form with unified properties.

The comparison of the spatial distribution of towers built in the 1980s and during the post-2000 period reflects the diversity of locations for new towers in the last ten years. Until the 2000s, the verticalization of European centres corresponded to a piecemeal modernization of business districts that accompanied the rise of global finance in property markets for office buildings (Lizieri, 2009). The construction of new towers in Europe was then mainly limited to international financial centres where the progressive elevation of heights contrasted with the sprawl of low and medium density suburbs around them and the diffusion of blanket regulations over historical centres (for instance, La Défense vs Central Paris, or Donau City vs Vienna inside the Ring). During the 2000s, on the other hand, tower projects proliferated in European cities, a process that can be understood as very much part of globalization and the financialization of real estate, even in cities that seem to be more marginal to these hyper-speculative economic markets (figure 3).

$<$ current Figure 3 about here $>$

In cities such as Madrid, Milan, Turin or Paris, a few monumental towers have come to break the silhouette of the cityscape, but without reaching the extent of London, where, as of 1 January 2015 , more than 400 tower projects were proposed, approved or under construction. The Chamartín district of Madrid has become home to the eponymous Cuatro Torres, while Barcelona has gone vertical with 
urban renewal operations at Fira de Barcelona or Diagonal Mar. South of the Alps, Milan has been gracing the covers of specialist journals following the construction of the Bosco Verticale, while Turin, not without opposition, allowed Renzo Piano to build Torre San Paolo. Further north, the Turning Torso has redefined the image of the city of Malmö in Sweden.

However, the post-2000 boom in vertical construction in Europe is not necessarily exemplified in super-tall futuristic structures such as the ones erected in Middle-Eastern and Asian cities, but in supposedly compact energy-efficient residential urban blocks according to new high-rise urbanism principles. Woven into the existing city fabric, these projects are often framed from the ground up, as initiatives to reinvigorate local deprived or de-industrialized neighbourhoods and to create urban amenities around transport nodes, embodying new sets of discourses and practices among built environment professionals and planning authorities (Appert, 2012). The particular historical context in urban Europe also gives much strength to heritage and conservation groups and lobbies who strongly shape the height outlines of the European urban landscape, prompting the need to closely examine the conditions of the emergence of a (renewed) European urban vernacular of contemporary high-rise urbanism (photograph Frankfort or Elephant and Castle).

$<$ Photograph Frankfort european skyline or London Elephant and Castle with Strata tower $>$

Considering this diversity of contemporary forms of high-rise urbanism, this issue of Built Environment explores a range of practices and manifestations across Europe according to three main perspectives: i) political economy ii) heritage and planning, and iii) symbolic landscapes. The first of these concern contemporary high-rise construction, demolition and maintenance, and is a core component of the papers by Craggs, Lenne, Hure et al., and Charney and Rosen. Following seminal works on the role of financial intermediaries and instruments in the verticalisation of North-American cities (Weber, 2015), these four papers explore how European cities are located on the emerging global map of investment flows and trace back the genealogy of entrepreneurial forms of verticalisation which started in 1970s. They offer insights on evolutions within international financial 
systems to show how the creation of new investment vehicles like REITs (Real Estate Investment Trusts) are driving (some of) the verticalization of European cities.

The physics of tall buildings and their architectural and engineering qualities have been the locus of a recent renewed interest (Al Kodmany, 2017); however the role of consultants and experts who guide investment and influence decision-makers, prioritize places and participate in the construction of what could be identified as a European tower market remains underexplored. In the fierce competition between European cities for attracting investment, we seem to be witnessing a new common urban sense in which the presence of high-tech towers would allow urban centres to distinguish themselves and signal their economic dynamism (Grubbauer, 2014). Built and run by a variety of intermediaries, this intra-European market for entrepreneurial verticalization is structured by such signals of local economic success. Like any market, it has echo chambers such as the MIPIM (Le marché international des professionnels de l'immobilier - the International Real Estate Professionals Trade Show, hosted in Cannes every March), an intense moment where professionals of this small economic world are now presented with new tower projects, "unveiled" with fanfare to attract investment.

The paper by Loïse Lenne explores the archaeology of contemporary commercial high-rise urbanism in the City of London by focussing on the history of one particular edifice, the Lloyd's Building, constructed in 1986 and designed by Richard Rogers and Partners. Archives and interviews with planners and architects, including Richard Rogers himself, provide the material for a detailed analysis of how the construction of this particular building was a turning point for the theory and practice of high-rise urbanism and tall buildings in the City. Having designed several of its architectural landmarks such as the Lloyd's Registers, 88 Wood Street or the recent the Leadenhall Building (completed in 2014), Rogers and his team have had a considerable influence on the physical fabric of the City. Lenne's paper examines how their first intervention in the Square Mile, The Lloyd's Building, set the principles that still underpin tall buildings projects in the City. Not particularly tall (95 metres high when Tower 42 completed in 1980 reached 183 metres), this buildings was nonetheless the only building of this size to be allowed at a time when high construction had been banned in the City. The debate around the building introduced new arguments where architectural 
quality was used as a ground to relax heritage regulations. Assessing the architectural qualities of the building, Lenne shows that it also represented a major change in the imaginary of the development of the City shifting from comprehensive public-led urban redevelopments to a piecemeal approach responding to the market needs.

If the architectural principles supporting the current wave of tall buildings in the City of London can be traced back to 1980s, David Cragg's paper explores how the recent surge in skyscrapers has been backed by a particular political economy which appears to be increasingly entangled with the dynamics of international property markets. Departing from the debates about the contested politics of tall buildings and the management of London's skyline, this paper critically assesses the financial forces driving the contemporary development of skyscrapers in London and questions the apparent consensus among the London's planning industry to support this highly speculative stage of high-rise urbanism. As the 2008-2010 crisis offered an opportunity for new institutional investors to acquire a share in the prime market of central London, it reinforced the position of London as a magnet for an ever expanding volume of capital searching for a return through the exploitation of the built environment. But the paper also exposes the fragility of the underpinnings of this vertical expansion, rooted on a "dependency on rising asset-prices, loose monetary policy and the wealth preserving instincts of the global financial elite". Reflecting on the patterns of capital accumulation through the built environment and its political regulation (or lack of) through planning, the paper also illustrates how the current growth of skyscrapers signals a profound shift in the ideology and spatial imaginaries that supported high-rise urbanism in Europe, particularly during the post-war period. While the commercial skyscrapers used to signal the peak of a building cycle in highly regulated markets and the mass production of housing was absorbing much of the resources (capital and labour), the current proliferation of isolated monumental structures serves the purpose of producing a continuous stream of rental revenues for a constellation of investors in a crisis-prone environment. This shift is also manifest in the very physicality of the built environment and the weakening of comprehensive, publicled large-scale urban development projects, progressively replaced by splintered forms of planning (Graham and Marvin, 2001). Interestingly enough, the scale of these rent machines has expanded 
(Santiago Calavatra's project for the Greenwich Peninsula has reached the stratospheric price of $£ 1$ billion) to the point where whole areas of European cities are again the subject of comprehensive private-led redevelopment, and developers are reinventing a wholesale high-rise urbanism targeted at securing different streams of rental revenues.

If understanding how the global restructuring of capital flows and the actions of market intermediaries may help in explaining some of the pressures towards verticalisation in European cities, this perspective needs to be supplemented by an exploration of how local political elites and planners also intervene in the production of towers. The paper by Maxime Huré, Christian Montès and Manuel Appert and the paper by Igal Charney and Gilad Rosen demonstrate that the somehow counterintuitive geography of contemporary verticalisation in Europe, far from only reflecting the geography and spatial conventions of real estate experts, finds its root in intense political and regulatory activity that needs to be unpacked. Using respectively the case of Lyon and Jerusalem, they show that the reemergence of towers in urban centres does not always flag the insertion of a city in highly financialized real estate markets, although it hints to entrepreneurial turning points in their urban policies (Charney and Rosen, 2016; Kaika, 2010). The evolution of the professional culture in architectural firms and planning authorities to adjust to vertical shifts and/or encourage it, and its adaptation to the demands and needs of international consultants is also part of this political mobilisation. Using numerous planning documents, media coverage and interviews with public figures, NGOs and real estate experts, their papers illustrate how a pro-growth agenda has dominated the development of tall buildings in both cities and toned down the polemics and controversies that characterised the previous rounds of high-rise projects. Both papers reflect on the politics of contemporary high-rise urbanism in each city and explore the response of the public to these important changes. In Jerusalem, where heritage planning and height limitations were introduced by British planners at the turn of the $20^{\text {th }}$ century, high-rises have triggered several waves of opposition coming from both NGOs and heritage experts. The impossibility to discuss in a meaningful manner the introduction of new tall buildings in the city and the absence of arenas where this debate could take place finally lead the authors to highlight the post-political or what we could even call non- 
political qualities of the debate. In Lyon, the introduction of a special policy guidance on tall buildings helped create a consensus among planning and heritage experts, politicians and residents associations who agreed on containing the construction of tall buildings near the main train station. However, the authors highlight that the very need for new tall buildings and skyscrapers in an economic context where the demands still seems limited was never openly discussed in public arenas.

The second core thematic shaping this issue's engagement with the dynamics of contemporary highrise urbanism in Europe concerns planning and heritage, and is a central aspect of the papers written by Greco and Nijhuis and Van der Hoeven. Looking at the cases of Lyon and Turin, Elena Greco's paper retraces how planning for tall buildings has evolved from the 1960 s to the new millennium. She shows how the first major wave of tall buildings in Lyon and Turin during the 1960s and 1970s materialized there the advent of the vertical modern city, yet despite being radically different from what was previously built, high-rise clusters were the result of strong planning regulations and codes that paradoxically related more to the urban fabric of these historical cities than the loose strategic guidelines developed more recently. Since the 1990s, in addressing processes of de-industrialization and looking for new economic resources, urban planning has become more negotiated, opening up opportunities for private sector actors to initiate high-rise developments in targeted areas or projets urbains. Accompanying forms of urban design have consequently changed, being reduced in scale to specific locations where tall buildings are expected and in the process losing sight of city-wide elements of design. The regulation of the European historic environment through the processes of conservation - institutionalized following effective or proposed radical transformations of cities - has come into direct collision with the latest tall building projects proposed as a means of leveraging economic development, fiscal revenues and rebranding cities. Steffen Nijhuis and Franklin Van der Hoeven illustrate this through the case of the Hague considering how high-rises can epitomize the predominance of economic development goals over urban planning principles, including the protection of urban heritage. Both these papers acknowledge the lack of consultation and assessment of the landscape impacts of tall buildings in Lyon, Turin and Dutch cities, despite existing tools and methodologies. Nonetheless, as an important rejoinder, Nijhuis and Van der Hoeven demonstrate how 
visibility analysis can overcome the subjectivity of perceived urban transformations often instrumentalised in debates surrounding high-rise construction. Landscape analysis through means of GIS-based modeling can often help planners and politicians map the visibility of tall buildings so as to better confine or design tall buildings in relation to the existing urban fabric.

The last four papers of the issue, working across social policy, film studies and urban geography, explore how the changing symbolic landscapes and cultural representations of high-rise urbanism in contemporary Europe need to be mapped directly onto new class relations and trajectories of neoliberal urbanism. All four of these papers, developing analysis of a range of material including audio-visual texts, planning documents and oral histories, chart in particular how the high-rise residential block has lost much of its post-War egalitarian and modernist social credentials. These have been largely superseded by a strong emphasis on upmarket lifestyles and investment priorities, and in the case of the UK and France have become part of a widespread and systematic programme of social housing demolition. In investigating the key intersections between political and cultural dimensions of high-rise life, these four papers not only provide sharp critical perspectives on the unequal vertical geographies emerging in Europe today, but emphasise how high-rise residential landscapes need to be understood as framed, sustained and negotiated through particular representational strategies and urban visions.

The paper by Essi Viitanen uses an in-depth analysis of four feature-length films from the last five years set in and around Helsinki to examine the relationship between high-rise urbanism and the changing social worlds of the Finnish suburbs, known as lähiö, associated from the 1950s with statebuilt modernist housing blocks. Viitanen assesses the way that cinematic space depicts and engages with new forms of everyday lived experience associated with the high-rise landscapes of these marginalised suburbs and the associated framing and play around themes of constraint, alienation and dysfunction. Also providing a focus on the way high-rise urbanism in Northern Europe has been mediated through film, Pei-Sze Chow's paper explores screen representations of Scandinavia's tallest building, the Turning Torso (2005) in Malmö, designed by the Spanish architect Santiago Calatrava, and regarded as the world's first 'twisted' skyscraper. Chow develops a close analysis, rooted in an 
emphasis on film as a form of social practice, of the documentary film Sossen, Arkitekten och det Skruvade Huset (2005) and the television crime drama series, Bron/Broen (2011-), that has found widespread international exposure on the wave of a 'Nordic Noir' trend. Chow uses these filmic texts to detail how this iconic example of high-rise European residential architecture is indicative of sharp tensions between welfare state ideology and neoliberal trajectories of post-industrial urbanism, in this case accompanying the development of the Øresund region straddling Southern Sweden and Copenhagen.

This emphasis on the unravelling of welfarist social policies through dramatically altered high-rise landscapes continues into the final two papers of this issue by Vincent Veschambre and Vikki McCall and Gerry Mooney. These take us to France, the European country with the greatest concentration of tower and slab blocks, and Glasgow, the European city with perhaps one of the highest number of high-rise social housing blocks. Both detail a similar story around the changing fortunes for towerblocks over the last half-century. Post-War idealism around their role in urban policy, part of what Veschambre calls an agenda of 'monumentalisation' in French social housing, quickly mutated to sustained disinvestment from the 1970s. Critically, this was accompanied by architectural discrediting of high-rise blocks and the stark territorial stigmatisation of areas where they were concentrated. The resulting negative narratives and discourses of 'failure' surrounding the people and places involved have been used by states and municipalities to justify and naturalise their demolition as the only response; a process Veschambre describes as 'deverticalisation'. The symbolic logic of this agenda of tower demolition perhaps reached an extreme apogee in the UK with plans, as McCall and Mooney document, to broadcast globally the blow-down of the Red Road towers in Glasgow as part of the opening ceremony to the 2014 Commonwealth Games.

Although these four papers overall portray a downbeat assessment of the socially progressive scope for high-rise living in contemporary Europe, exemplified by the horrific tragedy of the Grenfell Tower in London this year, they also offer crucial ways of reviewing the place for vertical life in European cities. Whether it is a focus on everyday multi-ethnic practices in suburban Helsinki, isolated examples of tower rehabilitation in the Rhône-Alpes region, documentary films that highlight the 
contradictions inherent to iconic vertical development, or the renewed radicalisation of the UK's housing crisis, these papers open up important new means of critically deconstructing - and in the process reconstructing - the social and political possibilities for the high-rise in the contemporary European imagination.

\section{References to be formated}

Al-Kodmany, Kheir (2017) Understanding tall buildings: a theory of placemaking. New York: Routledge.

Appert, Manuel (2012) Skyline Policy: The Shard and London's High-Rise Debate.

Metropolitics. http://www.metropolitiques.eu/Skyline-policy-the-Shard-and.html. (2016) The Resurgence of Towers in European Cities. Metropolitics. http://www.metropolitiques.eu/The-Resurgence-of-Towers-in.html.

Appert, Manuel, Huré, Maxime and Languillon, Raphaël (2017) Gouverner la ville verticale : Entre ville d'exception et ville ordinaire, Géocarrefour, 91/2, pp. 3-12.

Appleyard, Donald (1979) The Conservation of European Cities. Cambridge : MIT Press.

Backouche, Isabelle (2016) Paris transformé: le Marais, 1900-1980: de l'îlot insalubre au secteur sauvegardé. Paris: Créaphis.

Beeckmans, Luce (2014) The adventures of the French architect Michel Ecochard in postindependence Dakar: a transnational development expert drifting between commitment and expediency. The Journal of Architecture, 19/6, pp. 849- 71.

Charney, Igal, et Gillad Rosen (2014) Splintering Skylines in a Fractured City: High-Rise Geographies in Jerusalem. Environment and Planning D: Society and Space 32/ 6, pp. 1088- 1101.

Cohen, Jean-Louis (1995) Scenes of the world to come: European architecture and the American challenge, 1893-1960. Paris and Montréal: Flammarion; Canadian Centre for Architecture.

Delafons, John (1998) Politics and preservation: a policy history of the built heritage, 18821996. Studies in history, planning, and the environment 22. London: E \& FN Spon, 1997.

Drozdz, Martine, and Manuel Appert (2012) Re-Understanding the CBD : A Landscape Perspective. LATTS Working Paper available at https://halshs.archives-ouvertes.fr/halshs00710644

Esher, Lionel (1981) A Broken Wave: The Rebuilding of England, 1940-1980. London: Viking / Allen Lane, 1981.

Fredenucci, Jean-Charles (2003) L'entregent colonial des ingénieurs des Ponts et Chaussées dans l'urbanisme des années 1950-1970, Vingtième Siècle. Revue d'histoire, 79/3, pp. 79 - 91.

Gartman, David (2000) Why Modern Architecture Emerged in Europe, Not America: The New Class and the Aesthetics of Technocracy ». Theory, Culture \& Society 17/ 5, pp. 75 - 96. Graham, Stephen, and Lucy Hewitt (2013) Getting off the Ground On the Politics of Urban Verticality. Progress in Human Geography, 37/1, pp. 72-92. 
Graham, Stephen, and Marvin Steve (2001) Splintering Urbanism: Networked Infrastructures, Technological Mobilites and the Urban Condition. London: Routledge.

Glauser, Andrea (2016) Contested Cityscapes: Politics of Vertical Construction in Paris and Vienna. In Public Spaces: Times of Crisis and Change. Research in Urban Sociology 15. Emerald Group Publishing Limited, pp. 221-254.

Grubbauer, Monika. Architecture (2014) Economic Imaginaries and Urban Politics: The Office Tower as Socially Classifying Device. International Journal of Urban and Regional Research. 38/1, pp. 336- 59.

Harris, Andrew (2015) Vertical Urbanisms Opening up Geographies of the Three-Dimensional City. Progress in Human Geography, 39/5, pp. 601-20.

Hatherley, Owen (2016) Landscapes of Communism: A History Through Buildings. London: Penguin Books.

Jacobs, Jane M., Stephen Cairns, and Ignaz Strebel (2012) Materialising Vision: Performing a High-Rise View. Visuality/Materiality: Images, Objects and Practices, pp. 133-52.

Kaddour, Rachid (2016) The complex representations of working-class residential towers. The rise and fall of the Plein Ciel tower in three acts, Métropolitics.

Kaika, Maria (2010) Architecture and crisis: re-inventing the icon, re-imag(in)ing London and rebranding the City. Transactions of the Institute of British Geographers 35/4, pp. 453-474.

Kasmi, Amine (2017) The Plan as a Colonization Project: The Medina of Tlemcen under French Rule, 1842-1920. Planning Perspectives, 1 - 18 [advance preview at https://doi.org/10.1080/02665433.2017.1361335.

Lizieri Colin (2009) Towers of Capital : Offices Markets and International Financial Services, Chichester: Wiley-Blackwell.

Monclus, Javier, Dies Medina, Carmen (2016) Modernist Housing Estates in European Cities of the Western and Eastern Blocs, Planning Perspectives, 31/4, pp. 533-562.

Picard, Aleth (1994) Architecture et urbanisme en Algérie. D'une rive à l'autre (1830-1962). Revue du monde musulman et de la Méditerranée 73/1, pp. 121- 36.

Power, Anne (1993) Hovels to High Rise: State Housing in Europe Since 1850. London ; NewYork: Routledge.

Sailer-Fliege, Ulrike (1999) Characteristics of Post-Socialist Urban Transformation in East Central Europe, GeoJournal, 49/1, pp. 7-16.

Stanek, Lukasz (2012) Introduction: the 'Second World's' architecture and planning in the 'Third World.' The Journal of Architecture, 17, pp. 299-307.

https://doi.org/10.1080/13602365.2012.692597

Swenarton, Mark, Tom Avermaete, and Dirk van den Heuvel (2014) Architecture and the Welfare State. London; New York: Routledge.

Taillandier, Ingrid, Olivier Namias, Jean-François Pousse, et Pavillon de l'Arsenal (ed.) (2009) L'invention de la tour européenne. The invention of the European tower. Paris: Pavillon de l'Arsenal ; Picard. 
Turkington, R., van Kempen, R., Wassenberg, F., Onderzoeksinstituut (2004) High-Rise Housing in Europe: Current Trends and Future Prospects. Delft University Press.

http://resolver.tudelft.n1/uuid:87b875ba-46fa-4edf-97df-deeaf189d0a5

Verdeil, Eric (2012) Michel Ecochard in Lebanon and Syria (1956-1968). The Spread of Modernism, the Building of the Independent States and the Rise of Local Professionals of Planning, Planning Perspectives 27/2, pp. 249- 66.

Weber, Rachel (2015) From boom to bubble: how finance built the new Chicago. Chicago: The University of Chicago Press.

\section{Captions}

Figure 1: Number of towers constructed per decade in Europe since 1950. Source: Emporis and SKYLINE research project (2014).

Figure 2: Picture of Clermont

Add the picture of Warsaw as well?

Figure 3: Geographical location of towers constructed in Europe 1980-1999. Source: Emporis and SKYLINE research project. 2014

Figure 4: picture of Vienna

Figure 5: Geographical location of towers constructed in Europe 2000-2014. Source: Emporis and SKYLINE research project. 2014

Figure 6: picture of London 